\title{
Eksistensi peserta pelatihan kerja program pemagangan ilegal luar negeri khususnya di Jepang
}

\author{
Bilqis Fani Zulfakanti ${ }^{1}$, Agus Mulya Karsona ${ }^{2}$, Holyness Singadimedja ${ }^{3}$.
}

${ }^{1}$ Bilqis Fani Zulfakanti; Fakultas Hukum Universitas Padjadjaran; Jl. Raya Bandung Sumedang KM.21 Jatinangor; 45363; Jawa Barat; Indonesia.

${ }^{2}$ Agus Mulya Karsona; Fakultas Hukum Universitas Padjadjaran; Jl. Raya Bandung Sumedang KM.21 Jatinangor; 45363; Jawa Barat; Indonesia.

${ }^{3}$ Holyness Singadimedja; Fakultas Hukum Universitas Padjadjaran; Jl. Raya Bandung Sumedang KM.21 Jatinangor; 45363; Jawa Barat; Indonesia.

\section{A RT I CLEINFO}

Article history:

Received 2021-03-22

Received in revised form

2021-05-14

Accepted 2021-08-01

Kata kunci:

Pelatihan Kerja; Magang; Ilegal, Kepastian Hukum.

Keywords:

Job Training; Internship; Illegal, Legal Certainty.

DOI: https://doi.org/10.26905/

idjch.v12i2.4830.

How to cite item:

Zulfakanti, B.F., Karsona, A.M., Singadimedja, H., (2021). Eksistensi peserta pelatihan kerja program pemagangan ilegal luar negeri khususnya di Jepang. Jurnal Cakrawala Hukum, 12(2), 139-149. doi:10.26905/idjch.v12i2.4830.

Corresponding Author:

* Bilqis Fani Zulfakanti.

E-mail address: bilqisfaniz@gmail.com.

\section{Abstrak}

Program pemagangan di luar wilayah Indonesia sebagai salah satu bentuk pelatihan kerja dalam rangka pembangunan ketenagakerjaan memiliki peranan penting dalam mengatasi permasalahan tingginya Tingkat Pengangguran Terbuka di Indonesia. Dalam implementasinya, permasalahan terjadi ketika terdapat peserta pemagangan yang melarikan diri dari program pemagangan atau peserta pemagangan ilegal. Penulisan ini bertujuan untuk mengetahui dan memahami eksistensi peserta pemagangan ilegal termasuk berbagai akibat yang ditimbulkannya serta tindakan hukum yang dapat dilakukan oleh pemerintah Indonesia dalam mengatasi permasalahan tersebut. Penelitian menggunakan metode yuridis normatif dengan sumber data primer dan sekunder. Hasil penelitian menunjukan bahwa eksistensi peserta pemagangan ilegal di luar negeri yang melanggar peraturan perundangundangan baik di Indonesia maupun di negara penerima mengakibatkan hilangnya hak-hak peserta sebagai peserta pemagangan. Akibatnya, fasilitas keselamatan kerja, bantuan asuransi dalam hal terjadi kecelakaan kerja, gangguan kesehatan selama masa kerja, maupun kematian tidak dapat diakomodir, namun bantuan tetap dapat diberikan dalam konteks peserta pemagangan sebagai Warga Negara Indonesia. Kementerian Ketenagakerjaan RI dapat melakukan tindakan preventif berupa pembinaan dan pengawasan serta tindakan represif berupa upaya perundingan dengan pihak keluarga dan pencabutan izin LPK sementara. Adapun Kementerian Luar Negeri RI dapat memberikan bantuan hukum, bantuan dana untuk pengobatan, termasuk bantuan kepulangan peserta pemagangan ilegal. 


\begin{abstract}
Intern training program outside Indonesia region as a form of manpower development has significant role to overcome the high unemployment rate in Indonesia. In its implementation, the problem occurs wgen the participant of intern training program run away from the program or used to be called as illegal intern trainee. This paper aims to know and understand the existence of illegal intern trainee including the impacts, as well as legal actions that can be taken by Indonesia government to overcome the problems. This study is based on normative juridical approach with primary and secondary data sources. The study shows that the existence of illegal intern trainee that violate Indonesia's and accepting country's regulations causes loss of rights of the participant as intern trainee. As a consequence, ocupational safety facilities, and insurance assistance in the case of work accident, illness, nor mortality can not be accomodated, nonetheless assistance can still be given in the context of the illegal intern trainee status as Indonesian citizen. The Ministry of Manpower of the Republic of Indonesia can take preventif actions in the form of supervision and development and represive legal action by temporary revocate the sending organization's license. In the other hand, the Ministry of Foreign Affairs of the Republic of Indonesia can take represive legal actions in the form oflegal assistance, aid, including return assistance.
\end{abstract}

\section{Latar Belakang}

Pasal 27 ayat (2) Undang-Undang Dasar Negara Republik Indonesia Tahun 1945 (UUD 1945) pada dasarnya telah memberikan jaminan serta perlindungan hukum yang nyata bagi setiap warga negara atas hak untuk memperoleh pekerjaan. Hal ini berbanding terbalik dengan kenyataan tingginya Tingkat Pengangguran Terbuka (TPT) di Indonesia. Berdasarkan data yang dihimpun oleh Badan Pusat Statistik per Agustus 2019, jumlah TPT di Indonesia mencapai 7,05 juta orang (Badan Pusat Statistik, 2019). Adapun faktor penyebab tingginya TPT di Indonesia diantaranya yakni jumlah angkatan kerja yang tidak seimbang dengan jumlah lapangan pekerjaan (Franita, 2016) dan kurangnya keahlian atau keterampilan yang dimiliki oleh para pencari kerja (Direktorat Bina Pemagangan, 2004).

Salah satu upaya pemerintah dalam mengatasi permasalahan tingginya TPT di Indonesia yaitu melalui penyelenggaraan pelatihan kerja. Dalam hal ini, pemerintah telah memberikan landasan hukum pelaksanaan pelatihan kerja dalam
Undang-Undang Nomor 13 Tahun 2003 tentang Ketenagakerjaan (UUD Ketenagakerjaan). Berdasarkan Pasal 21 UU Ketenagakerjaan, pelatihan untuk meningkatkan keterampilan kerja ini dapat diselenggaraan melalui program pemagangan (on the job training). Selain dilakukan di dalam negeri, Pasal 24 UU Ketenagakerjaan mengatur bahwa pelaksanaan program pemagangan juga dapat dilakukan di luar wilayah Indonesia. Adapun Pasal 1 angka 1 Peraturan Menteri Tenaga Kerja dan Transmigrasi Republik Indonesia Nomor: PER.08/MEN/V/2008 tentang Tata Cara Perizinan dan Penyelenggaraan Pemagangan Luar Negeri (Peraturan Menteri Tenaga Kerja dan Transmigrasi Republik Indonesia Nomor: PER.08/ MEN/V/2008) mendefinisikan program pemagangan di luar negeri sebagai bagian dari sistem pelatihan kerja yang diselenggarakan secara utuh dan terpadu di Indonesia dan di luar negeri oleh lembaga pelatihan kerja (LPK) atau perusahaan atau instansi pemerintah atau lembaga pendidikan di bawah bimbingan dan pengawasan instruksi dan/atau pekerja yang lebih berpengalaman dalam proses produksi barang dan/atau jasa, dalam 


\section{Eksistensi peserta pelatihan kerja program pemagangan ilegal luar negeri khususnya di Jepang \\ Bilqis Fani Zulfakanti, Agus Mulya Karsona, Holyness Singadimedja}

rangka menguasai keterampilan atau keahlian tertentu.

Penyelenggaraan program pemagangan di luar negeri ini telah berlangsung sejak tahun 1993. Adapun Jepang merupakan negara yang memiliki hubungan intensif dengan pemerintah Indonesia dalam penyelengaraan program pemagangan di luar negeri. Berdasarkan data yang dihimpun oleh Direktorat Bina Pemagangan Kementerian Ketenagakerjaan Republik Indonesia, per tahun 2018, terdapat 20.000 peserta yang tengah melaksanakan program pemagangan dengan total jumlah peserta yang telah diberangkatkan Indonesia yaitu sebanyak 82.000 peserta (Direktorat Bina Pemagangan, 2019).

Apabila mengacu pada undang-undang perburuhan Jepang, program pemagangan ini disebut sebagai Jisshusei atau masa bekerja sembari berlatih. Secara umum, Jisshusei ini dilaksanakan dalam jangka waktu 1 (satu) hingga 3 (tiga) tahun dan dapat diperpanjang menjadi 5 (lima) tahun (Direktorat Jenderal Pembinaan Pelatihan dan Produktivitas, 2011). Adapun program pemagangan di Jepang ini terdiri dari (dua) jenis program yakni i) program pemagangan IMM Japan yang diselenggarakan berdasarkan Memorandum of Understanding (MoU) antara pemerintah Indonesia dalam hal ini Kementerian Ketenagakerjaan dengan The Association for International Manpower Development of Small and Medium Enterprises Japan; dan ii) program non-IMM Japan yang diselenggarakan berdasarkan MoU antara LPK atau Sending Organization (SO) di Indonesia dengan Lembaga Penerima atau Accepting Organization (AO (Yurikosari, 2008).

Selain memberikan dampak positif terhadap upaya mengurangi TPT di Indonesia, program pemagangan di luar negeri khususnya program pemagangan yang diselenggarakan oleh LPK swasta juga memberikan tantangan baru bagi pemerintah Indonesia. Hal ini karena dalam pelaksanaannya, peserta pemagangan seringkali dihadapkan pada berbagai permasalahan. Rangkaian permasalahan yang dihadapi peserta pemagangan tersebut terjadi baik pada tahap pra pemagangan, tahap pemagangan, maupun pasca pemagangan seperti besarnya biaya penempatan, ketidakjelasan proses pemberangkatan, dan kondisi peserta pasca pemagangan (Nola, 2018).

Permasalahan krusial timbul pada tahap pemagangan atau pada saat peserta pemagangan melaksanakan program pemagangan di negara penerima. Pada tahap ini, peserta pemagangan seringkali dihadapkan pada berbagai permasalahan diantaranya yaitu terjadinya kecelakaan kerja, perselisihan dengan perusahaan penerima, serta permasalahan peserta pemagangan ilegal. Adapun persoalan eksistensi peserta pemagangan ilegal ini menjadi tantangan tersendiri bagi pemerintah Indonesia. Berdasarkan data yang dihimpun oleh Japan International Training Cooperation Organization (JITCO), per Januari 2018, terdapat 66.498 orang asing dengan status ilegal yang berada di Jepang termasuk warga negara Indonesia. Adapun per tahun 2017, terdapat sebanyak 7.089 peserta pemagangan yang melarikan diri dari program pemagangan (Runaway Technical Intern Trainee). Dalam hal ini, Indonesia menyumbang persentase sebesar 3,4\% atau sebanyak 242 (dua ratus empat puluh dua) peserta pemagangan asal Indonesia yang melarikan diri dari program pemagangan (Japan International Training Cooperation Organization, 2018)

Pada dasarnya, Pasal 22 ayat (1) dan ayat (2) UU Ketenagakerjaan telah mengamanatkan bahwa pelaksanaan pemagangan di luar negeri dilaksanakan berdasarkan perjanjian pemagangan antara peserta dengan lembaga penyelenggara yang sekurang-kurangnya memuat ketentuan hak dan kewajiban peserta dan pengusaha serta jangka waktu pemagangan. Selain itu, pelaksanaan program pemagangan pun dilaksanakan dengan mengacu pada MoU antara lembaga penyelenggara pemagangan atau SO dengan lembaga penerima atau $\mathrm{AO}$ di Jepang. 
Sebagaimana tertuang dalam ketentuan perjanjian pemagangan, peserta pemagangan telah memperoleh penetapan perusahaan penerima, jangka waktu pemagangan, serta hak dan kewajiban peserta pemagangan, namun dalam pelaksanaannya peserta pemagangan yang telah diberangkatkan ke negara penerima secara legal justru berubah status menjadi peserta pemagangan ilegal. Berdasarkan hasil wawancara dengan Direktorat Bina Pemagangan Ketenagakerjaan Republik Indonesia, terdapat 2 (dua) kondisi yang memposisikan peserta pemagangan dikatakan sebagai peserta pemagangan ilegal yakni i) pertama, dalam jangka waktu pemagangan, peserta pemagangan tersebut melarikan diri dari perusahaan penerima yang telah ditentukan dalam perjanjian pemagangan dan bekerja di perusahaan lain di luar kesepakatan yang tertuang dalam perjanjian pemagangan; dan ii) kedua, setelah jangka waktu pemagangan berakhir, peserta pemagangan melarikan diri dari perusahaan penerima, bekerja di perusahaan lain dan tidak kembali ke Indonesia (Wawancara dengan Direktorat Bina Pemagangan Kementerian Ketenagakerjaan Republik Indonesia, 14 Januari 2020).

Menjadi persoalan lanjutan ketika permasalahan eksistensi peserta pemagangan ilegal di luar negeri khususnya di Jepang ini menimbulkan berbagai resiko yang lebih tinggi dimana berdasarkan hasil wawancara dengan salah satu peserta pemagangan ilegal di Jepang bahwa dalam pelaksanaanya, peserta pemagangan ilegal seringkali dihadapkan pada berbagai permasalahan seperti kecelakaan kerja, gangguan kesehatan selama masa kerja, kematian, hingga permasalahan hukum yang dihadapi peserta pemagangan ilegal selama berada di Jepang (Wawancara dengan salah satu peserta pemagangan ilegal di Jepang, 6 April 2020), namun dalam hal ini peraturan perundangundangan terkait penyelenggaran program pemagangan di luar negeri tidak dapat mengakomodir permasalahan tersebut.
Permasalahan-permasalahan di atas menimbulkan adanya sebuah urgensi untuk mengkaji dan menganalisis mengenai eksistensi peserta pemagangan ilegal di luar negeri khususnya di Jepang ditinjau dari peraturan perundang-undangan di Indonesia serta tindakan hukum yang dapat dilakukan dalam mengatasi permasalahan peserta pemagangan ilegal tersebut.

\section{Metode}

Metode pendekatan yang digunakan dalam penelitian ini yaitu metode pendekatan yuridis normatif, yaitu penulisan hukum yang digunakan dengan cara meneliti bahan pustaka atau data sekunder. Adapun penelitian ini bersifat deskriptif analitis dan evaluatif yakni memberikan gambaran atau penjelasan dan analisa secara konkret serta melakukan evaluasi terhadap kebijakan yang telah ditetapkan (Mamuji, 2007). Penulis melakukan penelitian kepustakaan yang terdiri dari bahan hukum primer yaitu bahan-bahan hukum yang mempunyai kekuatan hukum mengikat (Soemitro, 1982) terdiri dari UUD 1945, UU Ketenagakerjaan, dan Undang-Undang Nomor 37 Tahun 1999 tentang Hubungan Luar Negeri, bahan hukum sekunder yakni berupa tulisan-tulisan para ahli yang terdiri dari buku, jurnal ilmiah, dan artikel, serta bahan hukum tersier berupa kamus dan internet. Penulis juga melakukan penelitian lapangan dengan cara melakukan wawancara mendalam dengan Kementerian Ketenagakerjaan Republik Indonesia, Kementerian Luar Negeri Republik Indonesia, lembaga pelatihan kerja, dan peserta pemagangan ilegal.

\section{Pembahasan}

\section{Eksistensi Peserta Pelatihan Kerja Pro- gram Pemagangan Ilegal di Luar Negeri Khususnya di Jepang}

Manusia dapat bekerja dengan berusaha secara mandiri dengan menciptakan lapangan kerja 


\section{Eksistensi peserta pelatihan kerja program pemagangan ilegal luar negeri khususnya di Jepang}

Bilqis Fani Zulfakanti, Agus Mulya Karsona, Holyness Singadimedja

sendiri atau bekerja pada orang lain. Pekerjaan yang diusahakan sendiri mengandung arti manusia tersebut bekerja atas usaha modal dan tanggung jawab sendiri. Sedangkan bekerja pada orang lain adalah bekerja dengan bergantung pada orang lain, yang memberi Perintah dan mengutusnya, karena ia harus tunduk dan patuh pada orang lain yang memberikan pekerjaan tersebut (Budiastanti, 2020). Terkait dengan lapangan kerja yang di sediakan oleh pihak lain, dalam konteks program pemagangan yang diselenggarakan oleh LPK swasta, proses keberangkatan peserta pemagangan ilegal pada dasarnya dilakukan melalui tata cara penempatan yang telah sesuai peraturan perundang-undangan yang berlaku. Peserta pemagangan merupakan peserta pemagangan yang telah memenuhi persyaratan calon peserta pemagangan sebagaimana diatur dalam Pasal 8 Peraturan Menteri Tenaga Kerja dan Transmigrasi Republik Indonesia Nomor: PER.08/MEN/V/2008 yakni sekurang-sekurangnya berpendidikan SLTA atau sederajat dan persyaratan lain sesuai dengan kebutuhan program pemagangan. Peserta pemagangan ilegal ini juga diberangkatkan oleh lembaga penyelenggara atau LPK yang telah memperoleh izin resmi dari Kementerian Ketenagakerjaan Republik Indonesia sebagaimana telah disyaratkan oleh Pasal 4 Peraturan Menteri Tenaga Kerja dan Transmigrasi Republik Indonesia Nomor: PER.08/ MEN/V/2008. Pun peserta telah mengikuti seluruh rangkai seleksi mulai dari seleksi administratif hingga diberangkatkan sesuai peraturan yang berlaku baik peraturan perundang-undangan, peraturan LPK, termasuk peraturan perusahaan penerima.

Mengacu pada hasil wawancara bersama Direktorat Bina Pemagangan Kementerian Ketenagakerjaan dan Lembaga Pelatihan Kerja Mirai Nusantara, kondisi yang kemudian memposisikan peserta pemagangan menjadi peserta pemagangan ilegal, yakni Peserta pemagangan melarikan diri dari program program pemagangan dalam jangka waktu pemagangan (Runaway
Trainee) dan peserta pemagangan tidak kembali ke Indonesia setelah jangka waktu pemagangan berakhir (Overstayer Trainee).

Undang-Undang Ketenagakerjaan dan Peraturan Menteri Tenaga Kerja dan Transmigrasi Republik Indonesia Nomor: PER.08/MEN/V/2008 tidak memberikan pengaturan secara langsung berupa larangan bagi peserta pemagangan untuk melarikan diri dari program pemagangan maupun kewajiban untuk kembali ke Indonesia setelah jangka waktu pemagangan berakhir. Meskipun demikian, pengaturan larangan-larangan tersebut diatur secara tersirat melalui kewajiban dalam Pasal 21 huruf a Peraturan Menteri Tenaga Kerja dan Transmigrasi Republik Indonesia Nomor: PER.08/MEN/V/2008 yang mengatur bahwa peserta pemagangan di luar negeri berkewajiban untuk menaati perjanjian pemagangan.

Sebagai cerminan dualisme sifat Hukum Ketenakerjaan yang bersifat publik dan privat (Khakim, 2014), perlu sekiranya untuk meninjau perjanjian pemagangan sebagai dasar pelaksanaan program pemagangan di luar negeri. R. Subekti menyatakan bahwa dalam konsep hubungan hukum setiap pihak memiliki hak dan kewajiban dimana para pihak memiliki hak untuk menuntut sesuatu termasuk wajib mematuhi tuntutan yang diberikan oleh pihak lainnya (Subekti, 2001). Berdasarkan analisa penulis terhadap perjanjian praktek keterampilan kerja antara Lembaga Pelatihan Kerja Mirai Nusantara dengan salah satu peserta pemagangan ilegal yang diberangkatkan secara resmi oleh LPK tersebut, terdapat beberapa pelanggaran terhadap muatan perjanjian yang dilakukan oleh peserta pemagangan ilegal. Dalam menganalisa pelanggaran yang dilakukan oleh peserta pemagangan ilegal, Penulis mengkategorikan analisa menjadi 2 (dua) kategori.

Pertama yakni terkait peserta pemagangan yang melarikan diri dari program pemagangan dalam jangka waktu pemagangan. Dalam perjanjian pemagangan antara peserta pemagangan dengan 
LPK, terdapat pengaturan mengenai penetapan AO sebagai pihak yang menentukan perusahaan penerima tempat peserta pemagangan melaksanakan praktek keterampilan kerja berserta bidang keterampilan yang akan dilakukan. Namun dalam jangka waktu pemagangan, peserta pemagangan yang telah menandatangani perjanjian pemagangan tersebut melarikan diri dari program pemagangan dengan cara bekerja di perusahaan lain di luar dari perusahaan yang telah ditetapkan oleh $\mathrm{AO}$ sebagaimana termuat dalam perjanjian pemagangan.

Terkait dengan peserta pemagangan yang tidak kembali ke Indonesia setelah jangka waktu pemagangan berakhir, pelanggaran dilakukan terhadap ketentuan dalam perjanjian pemagangan yang menyatakan bahwa peserta pemagangan wajib menaati ketentuan dan peraturan perundang-undangan serta hukum yang berlaku selama masa praktek keterampilan. Secara teknis, pelanggaran yang dilakukan oleh peserta pemagangan ini dilakukan pada masa persiapan kembalinya peserta tersebut ke Indonesia yang berkisar antara 2 (dua) minggu sebelum hingga pada hari berakhirnya jangka waktu pemagangan. Peserta tersebut tidak lantas kembali ke Indonesia namun masih menetap di negara penerima untuk bekerja di perusahaan lain dengan status izin tinggal yang telah berakir. Dalam hal ini, Japan Immigration Control and Refugee Recognition Act mengatur bahwa apabila izin tinggal lewat dari 1 (satu) hari, maka menetapnya warga negara asing tersebut dinyatakan telah melanggar hukum karena melebihi masa izin tinggal dan status visa berubah menjadi visa ilegal (Council of Local Authorithis for International Relation Japan)

Baik peserta pemagangan yang melarikan diri maupun tidak kembali ke Indonesia, keduanya telah melanggar ketentuan dalam perjanjian pemagangan untuk taat terhadap hukum yang berlaku. Hal ini karena dengan bekerjanya peserta pemagangan ilegal di perusahaan lain, peserta pemagangan tersebut telah melanggar Immigration Control and Refugee Recognition Act yang mengatur bahwa hanya warga negara asing yang memiliki keahlian khusus atau specialist technical workers yang dapat bekerja dan secara tegas melarang tenaga kerja tanpa keahlian atau unskilled workers untuk bekerja di Jepang (Hayakawa, 2010).

Keberadaan peserta pemagangan ilegal tersebut berakibat pada timbulnya kerugian bagi berbagai pihak dalam pelaksanaan program pemagangan di luar negeri. Pertama, keberadaan peserta pemagangan ilegal mengakibatkan kerugian bagi LPK sebagai lembaga penyelanggara. Hal ini karena ketika terdapat peserta pemagangan yang melarikan diri dari program pemagangan, pihak perusahaan penerima akan memberikan denda kepada LPK berupa uang ganti rugi yang telah dikeluarkan oleh pihak perusahaan untuk mendatangkan peserta pemagangan ke perusahaan tersebut. Keberadaan peserta pemagangan ilegal juga berpengaruh pada hubungan kerja sama antara LPK dengan pihak $\mathrm{AO}$ di negara penerima dimana terdapat resiko pengurangan Training Order hingga pemutusan hubungan kerja sama yang dilakukan oleh pihak AO terhadap LPK. Kedua, yakni resiko kerugian bagi perusahaan yang mempekerjakan peserta pemagangan ilegal. Dalam hal keberadaan peserta pemagangan ilegal di perusahaan tanpa adanya dasar penunjukan dari $\mathrm{AO}$ sebagai pihak yang melakukan kerja sama dengan penyelenggara di Indonesia diketahui oleh pihak keimigrasian Jepang, maka Organization for Technical Intern Training (OTIT) sebagai lembaga pengawas perusahaan di Jepang akan memberikan denda sebesar 20.000.000 (dua puluh juta) yen atau sekitar 2 (dua) miliar rupiah kepada perusahaan yang mempekerjakan peserta pemagangan ilegal (Wawancara dengan Direktorat Bina Pemagangan Kementerian Ketenagakerjaan Republik Indonesia, 14 Januari 2020).

Sebagai bentuk pengaturan lanjutan atas pelanggaran-pelanggaran yang dilakukan oleh peserta pemagangan ilegal, Pasal 20 ayat (2) huruf c Peraturan Menteri Tenaga Kerja dan Transmigrasi Republik Indonesia Nomor: PER.08/ 
MEN/V/2008 menyatakan bahwa penyelenggara pemagangan di luar negeri berhak untuk memberhentikan peserta pemagangan yang melanggar perjanjian pemagangan.

Dalam hal LPK menggunakan haknya sebagaimana diatur dalam Pasal 20 ayat (2) huruf c Peraturan Menteri Tenaga Kerja dan Transmigrasi Republik Indonesia Nomor: PER.08/ MEN/V/2008 dan memutuskan untuk memberhentikan peserta pemagangan ilegal baik peserta pemagangan yang melarikan diri dari program pemagangan maupun peserta pemagangan yang tidak kembali ke Indonesia, maka seluruh hak-hak yang melekat pada peserta pemagangan sebagaimana diatur dalam Peraturan Menteri Tenaga Kerja dan Transmigrasi Republik Indonesia Nomor: PER.08/MEN/V/2008 dan perjanjian pemagangan tidak dapat diberikan.

Konsekuensi logis lanjutan terjadi terhadap berbagai kasus yang menimpa peserta pemagangan ilegal. Dalam praktiknya, peserta pemagangan ilegal harus dihadapkan pada situasi yang sangat riskan bagi keamanan dirinya (Pitoyo, 2006). Sebagaimana resiko-resiko yang dihadapi oleh peserta pemagangan legal pada umumnya, pemagangan ilegal seringkali mengalami kecelakaan kerja, gangguan kesehatan selama masa kerja, perselisihan dengan pihak perusahaan, termasuk kematian (Wawancara dengan salah satu peserta pemagangan ilegal di Jepang, 6 April 2020).

Berbeda halnya dengan peserta pemagangan legal, sebagai konsekuensi logis ketentuan Pasal 20 ayat (2) huruf c Peraturan Menteri Tenaga Kerja dan Transmigrasi Republik Indonesia Nomor: PER.08/MEN/V/2008, maka peserta pemagangan ilegal tidak dapat memperoleh hak atas asuransi keselamatan kerja dalam hal terjadi kecelakaan kerja, hak atas asuransi kesehatan dalam hal peserta pemagangan ilegal mengalami gangguan kesehatan selama masa kerja, hak atas asuransi kematian, termasuk hak atas fasilitas keselamatan kerja. Hal ini diperkeruh dengan fakta bahwa tidak terdapat perjanjian tertulis baik berupa perjanjian pemagangan maupun perjanjian tertulis dalam bentuk lain yang mengikat antara peserta pemagangan ilegal dengan perusahaan penerima.

Perlu digarisbawahi bahwa sebelum LPK menggunakan haknya untuk memberhentikan peserta pemagangan ilegal dari program pemagangan, terdapat kewajiban yang perlu dipenuhi oleh LPK sebagai lembaga penyelenggara yang memberangkatkan peserta pemagangan. Dalam hal ini, Pasal 21 ayat (1) Peraturan Menteri Tenaga Kerja dan Transmigrasi Republik Indonesia Nomor: PER.08/MEN/V/2008 mengatur bahwa penyelenggara pemagangan di luar negeri wajib untuk memulangkan peserta pemagangan baik yang telah selesai mengikuti program magang maupun yang melanggar perjanjian pemagangan.

Abdul Khakim mengemukakan bahwa keberadaan hukum ketenagakerjaan secara yuridis ditujukan untuk menjaga keseimbangan antara pekerja/buruh dengan pengusaha agar terciptanya keharmonisan dan ketenangan kerja atau disebut sebagai industrial peace (Khakim, 2014). Artinya selain memberikan perlindungan pekerja, hukum ketegakerjaan juga memberikan perlindungan terhadap pengusaha, dan vice versa. Meskipun keberadaan peserta pemagangan ilegal ini mengakibatkan kerugian bagi berbagai pihak, namun kita tetap tidak bisa mengesampingkan berbagai persoalan lanjutan yang dihadapi peserta pemagangan ilegal seperti kecelakaan kerja, gangguan kesehatan selama masa kerja, dan berbagai resiko kerja karena minimnya fasilitas keselamatan kerja.

Sebagai bentuk lanjutan amanat Pasal 28D ayat (1) UUD 1945, UU Hubungan Luar Negeri mengatur bahwa perwakilan Indonesia berkewajiban untuk memberikan pengayoman, perlindungan dan bantuan hukum bagi warga negara dan badan hukum Indonesia di luar negeri sesuai dengan peraturan perundang-undangan nasional serta hukum dan kebiasaan internasional. Berdasarkan ketentuan tersebut, meskipun keber- 
adaan peserta pemagangan ilegal mengakibatkan terjadinya pelanggaran terhadap berbagai peraturan perundang-undangan di Indonesia dan peraturan perundang-undangan di negara penerima sehingga menyebabkan hak-haknya sebagai peserta pemagangan tidak dapat diakomodir, namun hal tersebut tidak lantas menghilangkan hak-hak peserta pemagangan ilegal sebagai warga negara Indonesia. Hal ini karena penerapan Pasal 18 ayat (1) Undang-Undang Hubungan Luar Negeri tersebut dilakukan dengan mengacu pada asas nasionalitas. Oleh karenanya, selama peserta pemagangan ilegal di luar negeri tersebut berstatus sebagai warga negara Indonesia, maka peserta pemagangan tersebut berhak untuk mendapatkan perlindungan dari pemerintah Indonesia.

\section{Tindakan Hukum Pemerintah Indonesia dalam Mengatasi Permasalahan Eksistensi Peserta Pemagangan llegal di Luar Negeri Khususnya di Jepang}

\section{a. Kementerian Ketenagakerjaan Republik Indonesia}

\section{1) Tindakan Preventif}

Berdasarkan Pasal 37 Peraturan Menteri Tenaga Kerja dan Transmigrasi Nomor: PER.08/ MEN/V/2008, Kementerian Ketenagakerjaan dapat melakukan upaya preventif berupa pembinaan yang dilakukan di dalam negeri dan di luar negeri. Lebih lanjut, Pasal 36 ayat (1) Peraturan Menteri Tenaga Kerja dan Transmigrasi Nomor: PER.08/MEN/V/2008 mengatur bahwa LPK wajib melaporkan pelaksanaan pemagangan setiap 6 (enam) bulan kepada direktur jenderal dengan tembusan kepada dinas ketenagakerjaan provinsi dan kabupaten/kota.

Dalam prakteknya, seringkali LPK tidak menyerahkan laporan kegiatan penyelenggaraan program pemagangan di luar negeri sebagaimana telah diamanatkan oleh undang-undang. Hal ini dapat menjadi salah satu faktor lemahnya pene- gakan hukum dalam penyelenggaraan program pemagangan di luar negeri. Tidak dipenuhinya amanat tersebut mengindikasikan LPK sebagai lembaga penyelenggara tidak melakukan pengawasan intensif terhadap peserta pemagangan yang melakukan pemagangan di luar negeri. Oleh karenya pengabaian terhadap kewajiban pelaporan ini dapat menjadi salah satu keran pembuka kesempatan bagi peserta pemagangan untuk melarikan diri secara bebas dari program pemagangan.

Peraturan Menteri Tenaga Kerja dan Transmigrasi Nomor: PER.08/MEN/V/2008 sebagai peraturan teknis tentang penyelenggaraan program pemagangan di luar negeri tidak memberikan pengaturan yang jelas mengenai konsekuensi apabila amanat Pasal 36 ayat (1) Peraturan Menteri Tenaga Kerja dan Transmigrasi Nomor: PER.08/ MEN/V/2008 tersebut tidak dapat dipenuhi. Padahal sanksi ini memiliki peranan krusial dalam upaya penegakan hukum (Susanto, 2019).

Sebagai peraturan yang mengatur secara khusus mengenai teknis penyelenggaraan program pemagangan di luar negeri, seharusnya Peraturan Menteri Tenaga Kerja dan Transmigrasi Nomor: PER.08/MEN/V/2008 dapat mengakomodir segala pengaturan teknis demi terwujudnya kepastian hukum. Hal ini karena sanksi administratif memegang peranan krusial dalam penegakan hukum guna menciptakan tatanan kehidupan masyarakat yang sesuai tujuan hukum.

\section{2) Tindakan Represif}

Tindakan represif yang dapat dilakukan oleh Kementerian Ketenagakerjaan yakni berupa pencabutan izin terhadap LPK yang memiliki peserta pemagangan ilegal. Namun sebelum izin tersebut dicabut, pihak Kementerian Ketanagakerjaan memberikan kesempatan terlebih dahulu kepada LPK sebagai lembaga penyelenggara untuk melakukan upaya represif berupa perundingan dengan pihak keluarga peserta pemagangan ilegal (Wawancara dengan Direktorat Bina Pemagangan 
Kementerian Ketenagakerjaan Republik Indonesia, 14 Januari 2020).

LPK dapat meminta bantuan keluarga peserta pemagangan ilegal untuk membujuk peserta pemagangan ilegal tersebut agar kembali ke Indonesia dalam jangka waktu 1 minggu. Apabila dalam jangka waktu 1 minggu upaya bujukan tidak berhasil, maka Kementerian Ketenagakerjaan bersama dengan Dinas Tenaga Kerja terkait akan mendampingi LPK untuk berunding dengan pihak keluarga yang didampingi oleh RT/RW setempat dan aparat balai desa. Perundingan tersebut ditujukan untuk membuat surat pernyataan untuk kemudian ditandatangani oleh pihak keluarga bahwa pihak keluarga akan bertanggung jawab terhadap peserta pemagangan ilegal tersebut. Berdasarkan keterangan Kementerian Ketenagakerjaan Republik Indonesia, dalam hal pihak keluarga menyetujui, maka pencabutan izin terhadap LPK tidak akan dilakukan.

Terkait dengan tindakan represif pencabutan izin bagi LPK, tidak terdapat ketentuan terkait dengan sanksi administratif yang dibebankan kepada LPK dalam hal terdapat peserta pemagangan yang melarikan diri atau menjadi peserta pemagangan ilegal. Sementara secara konseptual, tindakan hukum merupakan tindakan berdasarkan peraturan perundang-undangan yang dapat menimbulkan akibat hukum (HR, 2006), oleh karenanya tindakan pencabutan izin terhadap LPK tidak dapat dilakukan karena tidak terdapat landasan hukum yang mendasari pencabutan izin tersebut.

\section{b. Kementerian Luar Negeri Republik Indonesia}

Tindakan hukum yang dilakukan oleh Kementerian Luar Negeri Republik Indonesia pada dasarnya dilakukan ketika peraturan perundangundangan terkait ketenagakerjaan tidak dapat mengakomodir pengaturan terkait berbagai permasalahan yang dihadapi peserta pemagangan ilegal di negara penerima. Perlindungan yang diberikan oleh pemerintah Indonesia sebagaimana diamanatkan oleh UUD dan UU Hubungan Luar Negeri dilakukan berdasarkan asas nasionalitas dengan tetap memperhatikan batasan-batasan sebagaimana dimuat dalam Peraturan Menteri Luar Negeri Nomor 5 Tahun 2018 tentang Perlindungan Warga Negara Indonesia di Luar Negeri. Artinya sepanjang peserta pemagangan ilegal tersebut berstatus sebagai warga negara Indonesia dan dapat dibuktikan kewarganegaraannya, maka peserta pemagangan ilegal tersebut berhak untuk memperoleh hak atas perlindungan dari pemerintah Indonesia.

Pasal 2 ayat (2) huruf b Peraturan Menteri Luar Negeri tentang Perlindungan Warga Negara Indonesia di Luar Negeri mengatur bahwa perlindungan pemerintah pada dasarnya tidak bersifat mengambil alih tanggung jawab perdata atau pidana individu serta mengedepankan pemenuhan kewajiban para pihak sebagaimana diatur dalam peraturan perundang-undangan dan/atau kontrak.

Terhadap kasus yang dihadapi peserta pemagangan ilegal yakni kecelakaan kerja dan gangguan kesehatan selama masa kerja, Pasal 2 ayat (2) huruf a Peraturan Menteri Luar Negeri tentang Perlindungan Warga Negara Indonesia di Luar Negeri menyatakan bahwa perlindungan terhadap WNI yang berada di luar negeri diberikan dengan mengedepankan prinsip keterlibatan pihak yang bertanggung jawab dan/atau berwenang sesuai dengan ketentuan peraturan perundang-undangan. Dalam hal ini, Kementerian Luar Negeri Republik Indonesia memandang permasalahan tersebut sebagai tanggung jawab pemberi kerja dari peserta pemagangan ilegal. Dalam hal peserta pemagangan ilegal tidak memiliki perjanjian kerja, maka tanggung jawab tetap melekat pada pemberi kerja tersebut.

Bantuan pemerintah Indonesia terhadap peserta pemagangan ilegal yang mengalami kecelakaan kerja ataupun gangguan kesehatan selama 


\section{Jurnal Cakrawala Hukum, Volume 12 No. 2 Agustus 2021}

ISSN PRINT 2356-4962 ISSN ONLINE 2598-6538

masa kerja baru dapat diberikan dalam hal tidak terdapat pihak-pihak yang dapat dimintakan pertanggung jawaban baik itu pemberi kerja, lembaga penyelenggara, maupun keluarga. Selain itu, pemberian bantuan juga baru dapat diberikan apabila peserta pemagangan ilegal tidak memiliki kapasitas untuk membiayai dirinya yang dibuktikan dengan Surat Keterangan Tidak Mampu (SKTM).

Pemberian bantuan dapat diberikan dengan cara pengajuan permohonan secara tertulis yang diajukan oleh peserta pemagangan ilegal atau kuasanya kepada Kementerian Luar Negeri dalam hal ini Direktorat Perlindungan WNI dan BHI dengan SKTM untuk selanjutnya ditinjau kelayakan peserta pemagangan ilegal tersebut untuk memperoleh bantuan terhadap permasalahan kecelakaan kerja dan/atau gangguan kesehatan yang dialaminya.

\section{Simpulan}

Eksistensi peserta pemagangan ilegal di lur negeri yang melanggar peraturan perundangundangan baik di Indonesia maupun di negara penerima mengakibatkan kerugian bagi banyak pihak termasuk LPK dan perusahaan penerima serta hilangnya hak-hak peserta sebagai peserta pemagangan. Akibatnya, fasilitas keselamatan kerja, bantuan asuransi dalam hal terjadi kecelakaan kerja, gangguan kesehatan selama masa kerja, maupun kematian tidak dapat diakomodir, namun bantuan tetap dapat diberikan dalam konteks peserta pemagangan sebagai Warga Negara Indonesia. Dalam mengatasi permasalahan tersebut, Kementerian Ketenagakerjaan dapat melakukan tindakan preventif berupa pembinaan dan pengawasan dan tindakan represif berupa upaya perudiningan dengan pihak keluarga atau pencabutan izin LPK sementara. Adapun terhadap peserta pemagangan ilegal yang mengalami masalah, Kementerian Luar Negeri dapat memberikan bantuan hukum, bantuan dana untuk pengobatan, termasuk bantuan kepulangan peserta pemagangan ilegal ke Indonesia.

\section{Daftar pustaka}

Adjie, Habib. 2008. Hukum Notaris Indonesia. Bandung: Refika Aditama.

Adjie, Habib. 2008. Sanksi Perdata dan Administratif Terhadap Notaris Sebagai Pejabat Publik. Bandung: Refika Aditama.

Firmansyah, Y.R., 2017. Kekuatan Hukum Akta Perdamaian yang Dibuat Dihadapan Notaris dan Putusan Akta Perdamaian Pengadilan. Jurnal Cakrawala Hukum, 8(2), pp.220-229.

Hadjon, Philipus M. 1993. Pemerintah Menurut Hukum (Wet-En Rechmatig Bestuur). Ctk. Pertama. Surabaya: Yuridika.

Kitab Undang-Undang Hukum Perdata.

Pratiwi, R.O., 2020. Perlindungan hukum bagi penerima wasiat terhadap notaris yang tidak melaporkan akta wasiat secara elektronik. Jurnal Cakrawala Hukum, 11(3).

Purbacaraka, Purnadi., dkk. 1983. Perundang-Undangan dan Yurisprudensi. Bandung: Citra Aditya Bakti.

Purwaningsih, Endang. 2011, Penegakan Hukum Jabatan Notaris Dalam Pembuatan Perjanjian Berdasarkan Pancasila Dalam Rangka Hukum. Jurnal ADIL, Jurnal Hukum Fakultas Hukum Yarsi. Vol. 2. No. 3 Desember 2011.

Semedi, Bambang. 2013. Penegakan Hukum Yang Menjamin Kepastian Hukum. Jakarta: Artikel Pusdiklat Bea dan Cukai.

Shubhan, M. Hadi. 2008. Hukum Kepailitan. Jakarta: Kencana Prenada Media Group.

Sudarsono. 2007. Kamus Hukum Edisi Baru. ctk. Kelima. Jakarta: Rineka Cipta.

Sutcipto, H.M.N. Purwo. 1995. Pengertian Pokok Hukum Dagang Indonesia Jilid 1, Pengetahuan Dasar Hukum Dagang. Jakarta: Djambatan.

Sutedi, Adrian. 2009. Hukum Kepailitan. Bogor: Ghalia Indonesia. 


\section{Eksistensi peserta pelatihan kerja program pemagangan ilegal luar negeri khususnya di Jepang}

Bilqis Fani Zulfakanti, Agus Mulya Karsona, Holyness Singadimedja

Undang-Undang Republik Indonesia Nomor 2 Tahun 2014 Tentang Perubahan Atas Undang-Undang Republik Indonesia Nomor 30 Tahun 2004 Tentang Jabatan Notaris.

Undang-Undang Republik Indonesia Nomor 30 Tahun 2004 tentang Jabatan Notaris.

Undang-Undang Republik Indonesia Nomor 37 Tahun 2004 tentang Kepailitan dan Penundaan Kewajiban Pembayaran Utang.
Wisnuwardhani, D.A., 2017. Implementasi Hak Pekerja Dalam Hal Upah di Kantor Notaris. Jurnal Cakrawala Hukum, 8(1), pp.33-43.

Budiastanti, D.E., Adnyana, G.N., Agustine, A.D. (2020). Aspek yuridis program e-karir dalam perspektif hukum Ketenagakerjaan. Jurnal Cakrawala Hukum. 11(2), 147-156. doi:10.26905/idjch.v11i2. 4397. 